\title{
Reproducibility and repeatability of hybrid propulsion systems operation indexes in test conditions
}

\begin{abstract}
The analysis of driving tests repeatability is an important issue in terms of measuring the parameters determining operating conditions of the engine and the vehicle. Most of the typical tests apply to powertrains systems or entire vehicles. This paper undertakes the issue of practical evaluation of the tests repeatability on test stands equipped with a hybrid drive system. A high reproducibility of driving tests using only the accelerator pedal settings was obtained. Also a significant battery charge level influence on the repeatability of selected parameters of the hybrid drive system in driving tests was proved. Such dependence on the level of battery charge was demonstrated for the vehicle speed, combustion engine speed and the degree of the combustion engine utilization, affecting at the same time the operating conditions of the electric motor.
\end{abstract}

Key words: driving tests, hybrid drive system, tests repeatability, operational indexes

\section{Odtwarzalność i powtarzalność wskaźników pracy układu napędu hybrydowego w warunkach badawczych}

\begin{abstract}
Analiza powtarzalności testów jezdnych jest zagadnieniem istotnym $w$ aspekcie pomiarów wielkości określających warunki pracy silnika i pojazdu. Większość typowych testów dotyczy badań silników lub pojazdów. W pracy podjęto tematykę praktycznej oceny powtarzalności testów badawczych na stanowisku wyposażonym w uktad napędu hybrydowego. Uzyskano duża odtwarzalność testów jezdnych przy wykorzystaniu jedynie nastaw pedału przyspieszenia. Wykazano duży wptyw stopnia naładowania akumulatora wysokonapięciowego na powtarzalność wybranych parametrów uktadu napędu hybrydowego w testach jezdnych. Zależność od stopnia naładowania akumulatora wykazują: prędkość pojazdu, prędkość obrotowa silnika spalinowego oraz stopień jego wykorzystania, co jednocześnie wptywa na warunki pracy silnika elektrycznego.
\end{abstract}

Słowa kluczowe: testy jezdne, układ napędu hybrydowego, powtarzalność badań, wskaźniki pracy

\section{Evaluation of the research tests repeatability}

\subsection{Engines tests on the test benches}

The type-approval tests of vehicle propulsion systems with maximum authorized total weight of more than $3.5 \mathrm{t}$ are carried out on the engine test bench. The characteristics of these tests are shown in details in papers $[8,9]$. The type-approval certificate of engines requires conducting research using the WHSC test (World Harmonized Stationary Cycle), ESC test (European Stationary Cycle), ETC test (European Transient Cycle) and WHTC test (World Harmonized Transient Cycle). The first two are so-called static tests. The remaining tests are dynamic and carried out at variable engine speed and load. The average engine speed and the average torque of the combustion engine tend to be larger in the ETC test compared to the WHTC test. For the type-approval certificate of engines of heavy vehicles is executed one measurement during each test [9]. Directive 1999/96/EC of the European Parliament indicates that the permissible changes of engine speed, torque and power in the ETC test shall be determined on the basis of the linear regression equation $y=a x+b$, the coefficients of which are given in Table 1.

In the WHTC test the deviations of the actual engine speed, torque and power from the set values are determined,

\section{Ocena powtarzalności testów badawczych}

\subsection{Badania silników na hamowni}

Homologacyjne badania układów napędowych pojazdów o dopuszczalnej masie całkowitej powyżej 3,5 t wykonuje się na hamowni silnikowej. Charakterystykę tych badań przedstawiono szeroko w pracach $[8,9]$. Homologacja silników wymaga prowadzenia badań z wykorzystaniem testów WHSC (World Harmonized Stationary Cycle), ESC (European Stationary Cycle), ETC (European Transient Cycle) oraz WHTC (World Harmonized Transient Cycle). Pierwsze dwa są tzw. testami statycznymi, dwa następne - testami dynamicznymi prowadzonymi przy zmiennej prędkości obrotowej oraz obciążeniu silnika. Średnia prędkość obrotowa i średni moment obrotowy silnika spalinowego są zazwyczaj większe w teście ETC niż w teście WHTC. Dla homologacji silników pojazdów ciężkich jest wykonywany jeden pomiar w każdym teście [9]. Dyrektywa 1999/96/EC Parlamentu Europejskiego wskazuje, że dopuszczalne zmiany prędkości obrotowej i momentu obrotowego oraz mocy w teście ETC wyznacza się na podstawie regresji liniowej o równaniu y = $=\mathrm{ax}+\mathrm{b}$, której współczynniki podano $\mathrm{w}$ tabeli 1 .

W teście WHTC wyznacza się odchylenia rzeczywistej prędkości, momentu obrotowego i mocy silnika od wartości zadanych także na podstawie regresji liniowej. Odchylenie 
Table 1. Linear regression tolerances in WHTC and NRTC tests $[4,6,7]$

Tabela 1. Tolerancje warunków prowadzenia testów WHTC oraz NRTC tests [4, 6, 7]

\begin{tabular}{|l|c|c|c|c|}
\hline Quantity/wielkość & Speed/prędkość & & Torque/moment obrotowy & Power/moc silnika \\
\hline Test & ETC, WHTC & NRTC & ETC, WHTC, NRTC & ETC, WHTC, NRTC \\
\hline $\begin{array}{l}\text { Standard error of estimate of y } \\
\text { on x/standardowy btąd }\end{array}$ & max. 100 rpm & $\begin{array}{c}\leq 5.0 \% \text { of maxi- } \\
\text { mum test speed }\end{array}$ & $\begin{array}{c}\text { max 13\% of maximum engine } \\
\text { torque/max 13\% momentu maksy- } \\
\text { malnego }\end{array}$ & $\begin{array}{l}\text { max 8\% of maximum engine po- } \\
\text { wer/ max 8\% mocy maksymalnej }\end{array}$ \\
\hline $\begin{array}{l}\text { Slope of the regression, a/ } \\
\text { wspótczynnik a }\end{array}$ & \multicolumn{2}{|c|}{$0.95-1.03$} & $0.83-1.03$ & $0.89-1.03$ \\
\hline $\begin{array}{l}\text { Coefficient of determination, R2/ } \\
\text { wspótczynnik determinacji }\end{array}$ & \multicolumn{2}{|c|}{ min. 0.97} & min. 0.85 (ETC - min. 0.88$)$ & min. 0.91 \\
\hline $\begin{array}{l}\text { y intercept of the regression } \\
\text { line, b/zmiana wspótczynnika } \\
\text { regresji }\end{array}$ & $\pm 50 \mathrm{rpm}$ & $\begin{array}{c}\leq 10 \text { per cent of } \\
\text { idle }\end{array}$ & $\begin{array}{c} \pm 20 \text { Nm or } \pm 2 \% \text { of maximum } \\
\text { torque whichever is greater/wybór } \\
\text { większej wartości }\end{array}$ & $\begin{array}{c} \pm 4 \mathrm{~kW} \text { or } \pm 2 \% \text { of maximum po- } \\
\text { wer whichever is greater } / \text { wybór } \\
\text { większej wartości }\end{array}$ \\
\hline
\end{tabular}

also on the basis of linear regression. The standard deviation of particular parameters and coefficients of the regression equation are also given in Table 1 in accordance with the guidelines of the GTR-4 [6].

The engines of the off-road vehicles are tested in accordance with the NRTC cycle (Non-Road Transient Cycle). The magnitude of the deviation of the actual speed, torque and power shall be determined in the same way as for the WHTC test [7]; however the tolerances are different than those in the WHTC test (Table 1).

\subsection{Tests of vehicles on the chassis dynamometer}

The tests of entire vehicles are carried out in the European Union during the NEDC test (New European Driving Cycle), in the United States - during FTP test and in Japan - in the 10-15 mode cycle. The European test involves smaller changes in the speed of the vehicle. In this test the maximum tolerance of the vehicle speed was determined at $\pm 2 \mathrm{kph}$, while the time tolerance was $\pm 1 \mathrm{~s}$ [5] (Fig. 1). The number of measurements is 3 , but it can be reduced to 1 or 2 [9].

The FTP test features a significant variation of the vehicle speed. For this test the following tolerances were determined: $\pm 2 \mathrm{mph}(3.2 \mathrm{~km} / \mathrm{h})$ from the defined speed profile during acceleration or braking, with a time tolerance of $\pm 1 \mathrm{~s}$. While achieving the maximum speeds, the tolerance is increased to $4 \mathrm{mph}(6.4 \mathrm{~km} / \mathrm{h})[10]$.

Current developments are to introduce a standardized worldwide WLTP test (Worldwide Harmonized Light Vehicles Test Procedure) taking into account the division into three classes of vehicles. Regardless of this division into classes, a fixed value of speed tolerance amounting to $2 \mathrm{~km} / \mathrm{h}$ has been introduced. This value can deviate from the assumed profile within a range of $1 \mathrm{~s}$. Speed tolerances greater than those defined are not be accepted; an exception is the change of the speed exceeding $2 \mathrm{~km} / \mathrm{h}$ which does not last longer than $1 \mathrm{~s}$. There should be no more than $10 \mathrm{such}$ deviations during the entire driving test [12].

The same values of the speed and time tolerances are valid for the NEDC test. The analysis of the coefficient of variation for the vehicle speed $\mathrm{V}_{\text {veh }}$ indicates that the value of $\mathrm{CoV}\left(\mathrm{V}_{\mathrm{veh}}\right)$ increases at low speed values (as then there occurs also constant driving speed tolerance). For this reason, an analysis of the coefficients of variation for vehicle speed standardowe poszczególnych wielkości oraz współczynniki równania regresji podano również $\mathrm{w}$ tabeli 1 zgodnie z wytycznymi GTR-4 [6].

Silniki pojazdów pozadrogowych testowane są według cyklu NRTC (Non-Road Transient Cycle). Wielkości odchylenia rzeczywistej prędkości, momentu obrotowego i mocy wyznacza się tak samo jak dla testu WHTC [7], jednak tolerancje są odmienne niż w teście WHTC (tab. 1).

\subsection{Badania pojazdów na hamowni podwoziowej}

Badania całych pojazdów prowadzi się w testach: w Unii Europejskiej - NEDC (New European Driving Cycle), w Stanach Zjednoczonych - FTP oraz w Japonii - w teście 10-15. Test europejski jest testem o mniejszych zmianach prędkości pojazdu. W teście tym określono, że maksymalna tolerancja prędkości pojazdu wynosi $\pm 2 \mathrm{~km} / \mathrm{h}$, natomiast tolerancja czasu wynosi \pm 1 s [5] (rys. 1). Wykonuje się 3 pomiary, przy czym ich liczba może być zmniejszona do 1 lub 2 [9].

Test amerykański FTP cechuje się dużą zmiennością prędkości pojazdu. Dla tego testu ustalono następujące tolerancje: $\pm 2 \mathrm{mph}(3,2 \mathrm{~km} / \mathrm{h})$ od założonego profilu prędkości podczas przyspieszania lub hamowania $\mathrm{z}$ tolerancją czasu $\pm 1 \mathrm{~s}$. Podczas uzyskiwania wartości maksymalnych prędkości tolerancja jest zwiększona do $4 \mathrm{mph}(6,4 \mathrm{~km} / \mathrm{h})$ [10].

Obecne działania zmierzają do wprowadzenia standaryzowanego światowego testu WLTP (Worldwide Harmonized Light Vehicles Test Procedure) uwzględniającego podział na trzy klasy pojazdów. Niezależnie od podziału na klasy, wprowadzono stałą wartość tolerancji prędkości wynoszącą $2 \mathrm{~km} / \mathrm{h}$. Wartość ta może ulegać zmianie od założonego profilu w zakresie $1 \mathrm{~s}$. Tolerancje powyżej $2 \mathrm{~km} / \mathrm{h}$ nie są akceptowalne. Wyjątek stanowi zmiana prędkości o ponad 2 $\mathrm{km} / \mathrm{h}$, która nie trwa dłużej niż $1 \mathrm{~s}$. Nie powinno być więcej niż 10 takich odchyleń na test jezdny [12].

Takie same wielkości tolerancji prędkości i czasu obowiązują w teście NEDC. Analiza współczynnika zmienności prędkości pojazdu $\mathrm{V}_{\text {veh }}$ wskazuje, że wartość $\operatorname{CoV}\left(\mathrm{V}_{\text {veh }}\right)$ zwiększa się przy małych wartościach prędkości (gdyż wówczas także występuje stała tolerancja prędkości jazdy). Z tego względu analizę współczynników zmienności prędkości pojazdu w teście małych prędkości UDC (Urban Driving Cycle) przedstawiono na rys. 1 (uwzględniono dwa prze- 


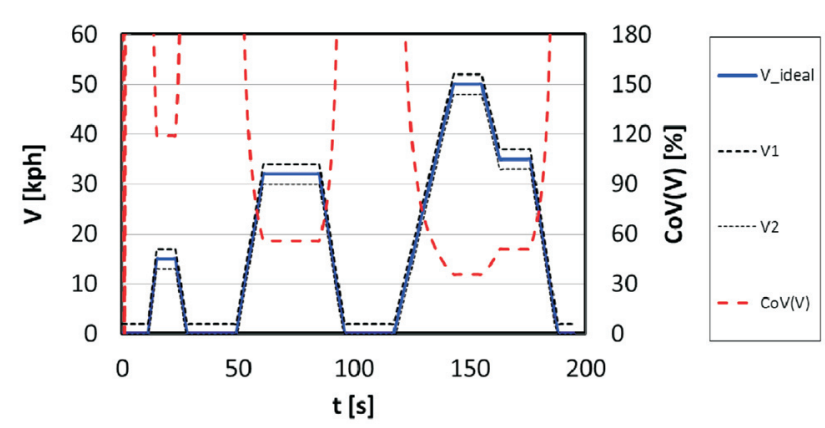

Fig. 1. Evaluation of the coefficient of variation from the mean value in the UDC test comprising a part of the NEDC test

Rys. 1. Ocena współczynnika zmienności prędkości od wartości średniej w teście UDC będącym częścią testu NEDC

in the low speeds UDC test (Urban Driving Cycle) is shown in Fig. 1 (includes two test runs with the extremely different - allowable - driving speeds). The figure proves that the increase in the speed of the vehicle determined in the UDC test reduces the coefficient of variation to a value of about $35 \%$. During the initial phase of the test (the first $30 \mathrm{~s}$ ), in the extreme case, the obtained $\operatorname{CoV}\left(\mathrm{V}_{\text {veh }}\right)$ value amounts to $120 \%$ (at a driving speed of about $15 \mathrm{kph}$ ).

\section{The aim of the research}

Tests of the hybrid drive systems are now an important part of the works aimed at determination the emissions of the exhaust gases in real driving conditions. For this reason, an attempt to evaluate the possibility of re-creating the operating conditions of such a drive system was undertaken. From the above characteristics it can be observed that it is not possible to unequivocally reproduce the conditions of hybrid drive system load; the same applies to combustion engines and conventional vehicles. Due to the complexity of the energy flow, only limited control over such a system is possible. Additionally, some research associated with the repeatability of the hybrid drive system response to the forced conditions was undertaken. Due to this the parameters significantly influencing repeatability of operating parameters of the hybrid drive system were determined.

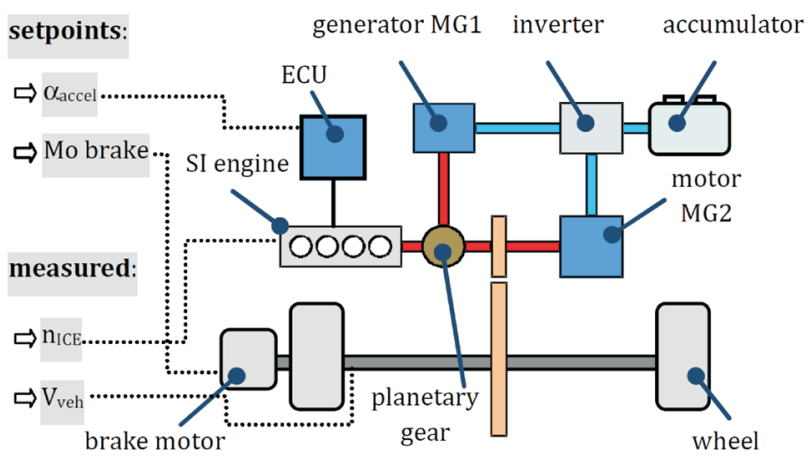

Fig. 2. The diagram of the test stand for determining the parameters of a combustion engine operation and a vehicle with hybrid drive system

Rys. 2. Schemat stanowiska do wyznaczania parametrów pracy silnika spalinowego i pojazdu z uktadem napędu hybrydowego jazdy o skrajnie różnych - dopuszczalnych - prędkościach jazdy). Z analizy rysunku wynika, że zwiększenie ustalonej prędkości pojazdu w teście UDC powoduje zmniejszenie współczynnika zmienności do wartości około 35\%. Podczas początkowej fazy testu (pierwsze $30 \mathrm{~s}$ ) - w skrajnym przypadku - uzyskuje się CoV( $\mathrm{V}_{\text {veh }}$ ) o wartości 120\% (przy prędkości jazdy wynoszącej około $15 \mathrm{~km} / \mathrm{h}$ ).

\section{Cel prac badawczych}

Badania układów napędów hybrydowych są obecnie ważnym elementem działań skierowanych na określenie emisji spalin w warunkach rzeczywistych. Z tego względu podjęto próbę oceny możliwości odtworzenia warunków pracy takiego układu napędowego. Z przedstawionej wyżej charakterystyki wynika, że nie jest jednoznacznie możliwe odtworzenie warunków obciążenia układu napędu hybrydowego, tak jak w silnikach spalinowych i pojazdach konwencjonalnych. Ze względu na złożoność przepływu energii jest możliwe ograniczone sterowanie takim układem. Dodatkowo podjęto prace związane z powtarzalnością odpowiedzi układu napędu hybrydowego na warunki wymuszenia. Dzięki temu określono wielkości wpływające znacząco na powtarzalność wskaźników pracy układu napędu hybrydowego.

\section{Metodyka badań}

\subsection{Obiekt badawczy}

Badania odtwarzalności i powtarzalności wskaźników pracy układu napędu hybrydowego przeprowadzono na mobilnym stanowisku demonstracyjnym, którego konstrukcja wykorzystuje podzespoły pojazdu Toyota Prius I generacji (rys. 2). Zastosowanie dodatkowego silnika elektrycznego podłączonego zewnętrznie do badanego układu napędowego umożliwia zadawanie pewnej wartości obciążenia symulującego, np. masę pojazdu i opory ruchu. W tabeli 2 przedstawiono charakterystyczne wielkości silnika spalinowego i elektrycznego wchodzące w skład omawianej konstrukcji.

Table 2. Characteristics of the tested vehicle

Tabela 2. Charakterystyka obiektu badawczego

\begin{tabular}{|l|c|c|c|}
\hline $\begin{array}{l}\text { Part of hybrid propul- } \\
\text { sion/element napędu } \\
\text { hybrydowego }\end{array}$ & Parameter & $\begin{array}{c}\text { Unit/ } \\
\text { jednostka }\end{array}$ & $\begin{array}{c}\text { Value/ } \\
\text { wartośćc }\end{array}$ \\
\hline \multirow{3}{*}{\begin{tabular}{l} 
SI engine \\
\cline { 2 - 4 }
\end{tabular}} & $\begin{array}{c}\text { Volume/obję- } \\
\text { tość skokowa }\end{array}$ & $\mathrm{cm}^{3}$ & 1497 \\
\cline { 2 - 4 } & $\mathrm{S} \times \mathrm{D}$ & $\mathrm{mm} \times \mathrm{mm}$ & $75.0 \times 84.7$ \\
\cline { 2 - 4 } & $\mathrm{Ne} / \mathrm{n}$ & $\mathrm{kW} / \mathrm{rpm}$ & $57 / 4500$ \\
\cline { 2 - 4 } & $\mathrm{Mo} / \mathrm{n}$ & $\mathrm{N} \cdot \mathrm{m} / \mathrm{rpm}$ & $115 / 4200$ \\
\hline \multirow{2}{*}{$\begin{array}{l}\text { motor MG2/silnik } \\
\text { MG2 }\end{array}$} & $\mathrm{No} / \mathrm{n}$ & $\mathrm{kW} / \mathrm{rpm}$ & $33 / 1040-5600$ \\
\cline { 2 - 4 } & $\mathrm{N} \cdot \mathrm{m} / \mathrm{rpm}$ & $350 / 0-400$ \\
\hline
\end{tabular}

\subsection{Aparatura badawcza i jej dokładność}

Warunki przebiegu testu jezdnego ustalano na podstawie wartości położenia pedału przyspieszenia. Nastawy tej wielkości, czas jej trwania oraz nastawy obciążenia zadawano z wykorzystaniem oprogramowania sterującego firmy Mechatronika. Wielkości te zadawano z rozdzielczością: $0,1 \%$ położenia pedału przyspieszenia (256 bitów), 


\section{Research methodology}

\subsection{Tested vehicles}

Research on reproducibility and repeatability of the hybrid drive system operating indexes was conducted on a mobile demonstration test-stand, which design uses components of the $1^{\text {st }}$ generation Toyota Prius vehicle (Fig. 2). The use of an additional electric motor attached externally to the tested drive system makes it possible to set a defined value of simulation load, e.g. simulation of the vehicle weight and resistance to motion. Table 2 shows the typical parameters of a combustion engine and electric motor included in the structure being described.

\subsection{Research apparatus and its accuracy}

The conditions of the test runs were based on the position of the accelerator pedal. Setting of this value, the time of test duration and setting the load were carried out with the use of the control software of Mechatronika company. These parameters were applied with the resolution of $0.1 \%$ of the accelerator pedal position ( 8 bits), resolution of $1 \mathrm{~s}-$ for duration of the phase and resolution of 127 steps ( 7 bits) for the load value. The program panel features, among others, the option of setting the position of the accelerator pedal through voltage simulation. For simulation a semiconductor digitalcontrolled potentiometer in hardware driver was used. As a standard, the (dual) potentiometer of the accelerator pedal is connected to the engine controller. During activation of the simulation, the original potentiometer is connected and replaced by a remotely controlled digital potentiometer.

The implemented features of the controller are: readout the wheel drive shaft speed, readout the torque from that shaft, setting the position of the accelerator pedal (electronic simulation) and setting the braking force (through the braking engine, present on the test stand, connected to the power supply).

The tests were carried out with the use of sensors integrated with the drive system. The main sensors include: an inductive sensor speed of the engine crankshaft mounted on a gear wheel (the number of teeth - 34), speed and torque sensors of electric machines, an accelerator pedal position sensor (doubled sensor with the output ranges of $0-5 \mathrm{~V}$ and $1.5-5 \mathrm{~V}$ ) and a Hall-effect sensor of the vehicle speed. The signals from the sensors mentioned were recorded with the use of dedicated diagnostic software through OBD II connection of the vehicle. Transmission system ISO 9141-2 was used with transfer speed of $10.4 \mathrm{kbit} / \mathrm{s}$. A serial data transmission system made it possible to achieve sampling frequency of about $0.7 \mathrm{~Hz}$ during the readout of one parameter (total number of parameters read-18).

\subsection{The conditions and the scope of the study}

The tests were carried out for different levels of the high voltage battery charge - SOC (state of charge). Previous authors studies $[2,3]$ indicated the importance of this indicator values in terms of the hybrid drive system operating conditions. For this reason, the tests were divided according to the value of the battery charge. The initial state of charge was defined at the level: $45 \%$ (three repetitions), about 54\%
$1 \mathrm{~s}$ - czas trwania modu (czyli fazy) oraz 127 kroków (bitów) wartości obciążenia. Panel programu wyposażono m.in. w opcję zadawania położenia pedału przyspieszenia przez symulację napięciową. Do symulacji zastosowano potencjometr półprzewodnikowy sterowany cyfrowo, znajdujący się w sterowniku sprzętowym. Standardowo do sterownika silnika podłączony jest potencjometr (podwójny) pedału przyspieszenia. Przy aktywacji symulacji oryginalny potencjometr jest odłączany, a w jego miejsce jest włączany potencjometr cyfrowy zdalnie sterowany z programu.

Zaimplementowane funkcje sterownika to odczyt prędkości obrotowej wału napędowego kół, odczyt momentu obrotowego z powyższego wału, zadawanie położenia pedału przyspieszenia (symulacja elektroniczna) oraz zadawanie siły hamowania (przez istniejący na stanowisku silnik hamujący połączony z zasilaczem prądu).

Badania wykonano przy zastosowaniu czujników wchodzących w skład układu napędowego. Główne z nich to: indukcyjny czujnik prędkości obrotowej wału korbowego silnika spalinowego zamontowany na kole zębatym (o 34 . zębach), czujniki prędkości i momentu obrotowego maszyn elektrycznych, czujnik położenia pedału przyspieszenia (zdwojony czujnik o zakresach wyjściowych: $0-5 \mathrm{~V}$ oraz 1,5-5 V), hallotronowy czujnik prędkości pojazdu. Rejestracji sygnałów z wymienionych czujników dokonano, stosując dedykowane oprogramowanie diagnostyczne przez złącze OBD II pojazdu. Wykorzystano system transmisji ISO 9141-2 o szybkości 10,4 kbit/s. Szeregowy system transmisji danych umożliwiał uzyskanie częstotliwości próbkowania o wartości około $0,7 \mathrm{~Hz}$ podczas odczytu jednej wielkości (łącznie odczytywano 18 wielkości).

\subsection{Warunki i zakres badań}

Badania prowadzono przy zróżnicowanym poziomie naładowania SOC (state of charge) akumulatora wysokonapięciowego. Wcześniejsze badania autorów prac [2, 3] wskazują na duże znaczenie wartości tego wskaźnika w aspekcie warunków pracy hybrydowego układu napędowego. $\mathrm{Z}$ tego powodu dokonano podziału badań zależnie od wartości naładowania akumulatora. Początkowy stan określono na poziomie: $45 \%$ (trzy powtórzenia), około 54\% (cztery powtórzenia) oraz 75\% (dwa powtórzenia). Liczba powtórzeń badań symulujących warunki drogowe nie była duża, co powodowało, że nie osiągnięto wymaganej liczby typowych badań statystycznych (liczba prób zbliżona do 30 [11]). $Z$ tego powodu zastosowano wskaźnik t-Studenta, $\mathrm{t}_{\mathrm{s}}$ jako miarę umożliwiającą zwiększenie rozrzutu przy mniejszej liczbie próbek (podrozdz. 3.4).

Analiza zmian wartości stopnia rozładowania akumulatora wysokonapięciowego pojazdu hybrydowego wykazuje jednoznaczną tendencję do jego rozładowania podczas dużych początkowych wartości SOC (rys. 3). Podczas przeprowadzonego testu dla wstępnego naładowania wynoszącego $75 \%$ uzyskano rozładowanie układu o około 6\% wartości początkowej. Przy tak dużej wartości wstępnego naładowania układ w minimalnym stopniu wykorzystywał silnik spalinowy (jedynie ze względu na chwilowe zapotrzebowanie na moc napędu), natomiast w sytuacji minimalnego 
(four repetitions) and 75\% (two repetitions). The number of repetitions of the tests simulating road conditions was not high, for which reason the sample size required of typical statistical surveys was not reached (size close to 30 [11]). Because of this, the student's t-test index $t_{s}$ was used as a measure allowing to increase the distribution for smaller size of the sample (section 3.4).

Analysis of the changes in the state of charge/discharge of high-voltage battery of the hybrid vehicle indicates an explicit trend for the initial values of the system charge (Fig. 3 ). During the test conducted for the initial state of charge of $75 \%$ the system was discharged by about $6 \%$ of the initial value. At such a high value of the initial charge, the system used the combustion engine at a minimum level (only in case of momentary demand for driving power). However, in case of the minimum initial charge $\mathrm{SOC}=45 \%$, the system responded with the extended operating time of the combustion engine, making it possible to achieve a charge at a level of about $9 \%$. For the initial charge degree of about $54 \%$ the system has not demonstrated any unequivocal trend of charging/discharging the HV battery. For two repetitions the charging achieved $-4.31 \%$, whereas for other repetitions the system increased the SOC level by $0.79 \%$.

\subsection{The method of analysis of the results}

The tests presented the input signals controlled by the driver (the signal depended on the position of the vehicle accelerator pedal), the battery charge level (SOC) and the speed affecting the value and repeatability of parameters characterizing the operating conditions of the 1st generation hybrid drive system in Toyota Prius.

One shortcoming of the presented test stand is that the inertia resistance, aerodynamic resistance, rolling resistance and resistance related to the topography of the terrain are not taken into account. However, the tests in real-road conditions are characterized by significant non-repeatability, due to the presence of numerous independent external factors, such as traffic congestion, traffic light cycles, weather conditions, etc.

For these reasons, the descriptive statistics tools were used, such as:

- sample standard deviation - this is a measure of the distribution of measurement results around the arithmetic mean of the sample. High standard deviation values indicate significant distribution of results around the mean $[1,11]$ :

$$
s(x)=\sqrt{\frac{1}{n-1} \sum_{i=1}^{n}\left(x_{i}-x_{a v}\right)^{2}}
$$

where: $\mathrm{n}-$ is the number of measurements, $\mathrm{x}_{\mathrm{i}}-$ is the value of the $\mathrm{i}$-th measurement, $\mathrm{x}_{\mathrm{av}}$ - is the arithmetic mean,

- the coefficient of variation $(\mathrm{CoV})$, is the measure of variation in the distribution of a parameter; unlike the standard deviation, which specifies an absolute variation of a parameter, the coefficient of variation is a relative measure, that is, depending on the value of the arithmetic mean [1]:

$$
\operatorname{CoV}(\mathrm{x})=\frac{\mathrm{s}(\mathrm{x})}{\mathrm{x}_{\mathrm{av}}}
$$

naładowania wstępnego, $\mathrm{SOC}=45 \%$, układ odpowiedział wydłużonym czasem pracy silnika spalinowego, co umożliwiło doładowanie na poziomie około $9 \%$. Dla początkowego stopnia naładowania wynoszącego około 54\% układ nie wykazał jednoznacznej tendencji do ładowania/rozładowywania akumulatora HV. Dla dwóch powtórzeń uzyskano rozładowanie $-4,31 \%$, natomiast dla pozostałych powtórzeń układ zwiększył poziom SOC o $0,79 \%$.

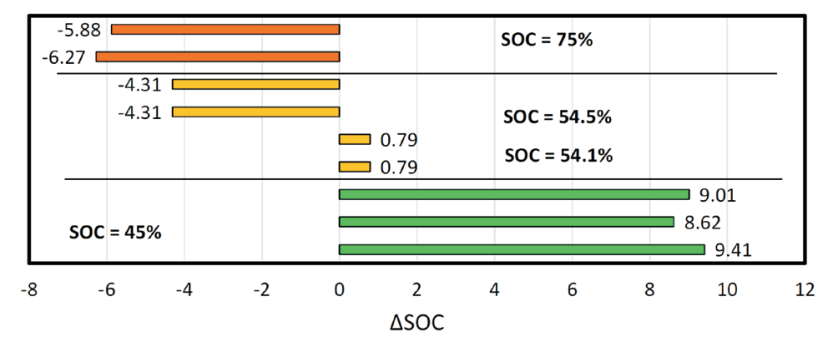

Fig. 3. The change of SOC value during the entire tests

Rys. 3. Zmiana stopnia naładowania akumulatora (SOC) podczas catego testu

\subsection{Sposób analizy wyników}

$\mathrm{W}$ badaniach przedstawiono wymuszenia zadawane przez kierowcę (wymuszenie to zadawano przez ustawienie pedału przyspieszenia pojazdu), poziom naładowania akumulatorów (SOC) oraz prędkość jazdy wpływającą na wielkość i powtarzalność parametrów charakteryzujących warunki pracy hybrydowego układu napędowego Toyoty Prius I generacji.

Pewną niedoskonałością prezentowanego stanowiska jest brak uwzględnienia oporów bezwładności, oporów aerodynamicznych, oporów toczenia, oporów związanych $\mathrm{z}$ topografią terenu. Jednak badania $\mathrm{w}$ rzeczywistych warunkach cechują się znaczną niepowtarzalnością, z powodu występowania wielu niezależnych czynników zewnętrznych, takich jak kongestia ruchu, cykle sygnalizacji świetnej, warunki atmosferyczne itd.

Z powyższych powodów wykorzystano narzędzia statystyki opisowej w postaci:

- odchylenia standardowego z próby - jest to miara rozproszenia wyników pomiarów wokół średniej arytmetycznej próby. Duże wartości odchylenia standardowego świadczą o dużym rozproszeniu wyników wokół średniej - wzór (1) $[1,11]$, gdzie: $n$ - liczba pomiarów, $x_{i}$ - wartość i-tego pomiaru, $x_{a v}$ - średnia arytmetyczna,

- współczynnika zmienności (CoV) - jest to miara zróżnicowania rozkładu cechy; w odróżnieniu od odchylenia standardowego, które określa bezwzględne zróżnicowanie cechy, współczynnik zmienności jest miarą względną, czyli zależną od wielkości średniej arytmetycznej - wzór (2) [1], gdzie: s(x) - odchylenie standardowe z próby, $\mathrm{x}_{\mathrm{av}}-$ średnia arytmetyczna,

- zmiennej losowej rozkładu t-Studenta; jej uwzględnienie jest konieczne ze względu na oszacowanie przedziału, w którym leży rzeczywista wartość mierzona; przedział ten szacuje się z określonym prawdopodobieństwem (tab. 3), gdy dokona się n pomiarów i znana jest wartość średnia 
where: $s(x)-$ is the standard deviation from the sample, $\mathrm{x}_{\mathrm{av}}-$ is the arithmetic mean,

- random variable of student's t-test distribution $t_{s}$. It is necessary to take that into account in order to assess the range within which an actual measured value lies. This range is assessed with a specified probability (Table 3 ) if $\mathrm{n}$ measurements were carried out and the mean and standard deviation from the sample are known, while the standard deviation from the population remains unknown.

Table 3. Student's t-test statistics for the significance level $\alpha=0.1$ [1]

Tabela 3. Statystyka t-Studenta dla poziomu istotności $\alpha=0,1$ [1]

\begin{tabular}{|c|c|}
\hline $\begin{array}{l}\text { The number of degrees of freedom } \mathrm{k} / \\
\text { liczba stopni swobody } \mathrm{k}\end{array}$ & statistics/statystyka $\mathrm{t}_{\alpha, \mathrm{k}}$ \\
\hline 1 & 6.314 \\
\hline 2 & 2.920 \\
\hline 3 & 2.353 \\
\hline 4 & 2.132 \\
\hline 5 & 2.015 \\
\hline 6 & 1.943 \\
\hline 7 & 1.895 \\
\hline 8 & 1.860 \\
\hline
\end{tabular}

Due to the small number of measurements, the meter equation (2) was proportionately increased by a value of student's t-test statistics:

$$
\operatorname{CoV}(\mathrm{x})=\frac{\mathrm{s}(\mathrm{x}) \cdot \mathrm{t}_{\alpha, \mathrm{k}}}{\mathrm{x}_{\mathrm{av}}}
$$

where: $\mathrm{s}(\mathrm{x})$ - is the standard deviation from the sample, $\mathrm{x}_{\mathrm{av}}$ - is the arithmetic mean, $\mathrm{t}_{\alpha, \mathrm{k}}$ - random variable of the student's t-test distribution, $\alpha-\mathrm{a}$ level of significance, $\mathrm{k}-$ the number of degrees of freedom equal to the number of measurements reduced by 1 .

\section{Analysis of the operating conditions reproducibility of hybrid drive systems}

\subsection{Forcing conditions of vehicle movement through setting of an accelerator system}

The hybrid drive system was controlled by simulated setting of the accelerator pedal - a change of the output voltage value from the accelerator pedal. Figure 4 shows the characteristics of changes of this input in each test. The calculated coefficient of variation $-\operatorname{CoV}\left(\alpha_{\text {acc }}\right)-$ was less than $2 \%$, which indicates repeatability of the settings. Only at the measuring points, in which a change of the input signal took place, the increased values of the coefficient of variation were observed. The reason for this is lack of full synchronization of the first measuring points in each test and a variable sampling frequency.

\subsection{Assessment of the vehicle speed as a reaction of the system to the input signal}

An algorithm describing the control over the tested vehicle is presented in Fig. 5. The control unit of the system (ECU) was supplied with a signal corresponding to a specified setting of the accelerator pedal position. Then the driver processed the i odchylenie standardowe z próby; nieznane jest natomiast odchylenie standardowe z populacji.

Ze względu na małą liczbę pomiarów, licznik równania (2) proporcjonalnie powiększono o wartość statystyki t-Studenta - wzór (3), gdzie: s(x) - odchylenie standardowe $\mathrm{z}$ próby, $\mathrm{x}_{\mathrm{av}}-$ średnia arytmetyczna, $\mathrm{t}_{\alpha, \mathrm{k}}-\mathrm{zmienna}$ losowa rozkładu Studenta, $\alpha$ - poziom istotności, $\mathrm{k}$ - liczba stopni swobody równa liczbie pomiarów pomniejszonej o 1 .

\section{Analiza odtwarzalności warunków pracy układu napędu hybrydowego}

\subsection{Wymuszenie warunków ruchu pojazdu przez nastawę układu przyspiesznika}

Sterowanie układem napędu hybrydowego odbywało się za pomocą symulowanej nastawy pedału przyspieszenia - zmiany wartości napięcia wyjściowego z elementu przyspiesznika. Na rysunku 4 przedstawiono przebieg zmian tego wymuszenia w poszczególnych próbach. Obliczony współczynnik zmienności $\operatorname{CoV}\left(\alpha_{\text {acc }}\right)$ przyjmował wartości poniżej $2 \%$, co świadczy o powtarzalności nastaw. Jedynie w punktach pomiarowych, w których następowała zmiana zadanego wymuszenia widoczne jest zwiększenie wartości współczynnika zmienności. Powodem tego jest brak pełnej synchronizacji pierwszych punktów pomiarowych poszczególnych prób oraz zmienna częstotliwość próbkowania.

\subsection{Ocena prędkości pojazdu jako odpowiedzi układu na wymuszenie}

Algorytm opisujący sterowanie obiektem badań przedstawiono na rys. 5. Do jednostki sterującej układu (ECU) dostarczany był sygnał odpowiadający określonej nastawie położenia pedału przyspieszenia. Następnie sterownik przetwarzał dostarczony sygnał i przesyłał go do elementów wykonawczych układu (ICE - silnik spalinowy, MG1 - sil-

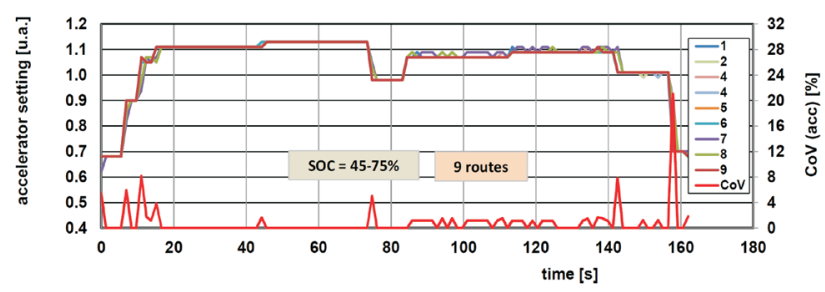

Fig. 4. Analysis of the input signal conditions Rys. 4. Analiza warunków wymuszenia

nik elektryczny/generator prądu, MG2 - silnik elektryczny/ generator prądu). Przetwarzane sygnały uwzględniały zakłócenia (w postaci zmiany oporów ruchu wywołane masami bezwładności oraz hamulcem elektrycznym) mające wpływ na końcowe warunki pracy układu napędu hybrydowego. W bieżących badaniach nie uwzględniono sprzężenia zwrotnego zadanej prędkości jazdy (przerywana linia na rys. 3). Brak weryfikacji prędkości pojazdu i wynikającej z tego korekty zadanej nastawy pedału przyspieszenia przyczyniły się do uzyskania znacznych różnic w prędkości jazdy, zależnych bezpośrednio od stopnia naładowania akumulatora.

Rejestracja parametrów pracy układu odbywała się z częstotliwością ok. 0,7 Hz. Zakres zmian częstotliwości 
delivered signal and transmitted it to the system actuators (ICE - a combustion engine, MG1 - an electric motor/generator, MG2 - electric motor/generator). The processed signals took into account interference (in the form of changes to the motion resistance caused by the inertia mass and electric brake) which influenced the final operating conditions of the hybrid

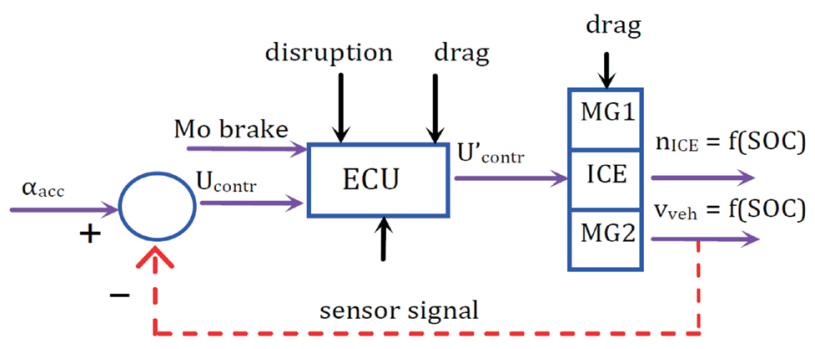

Fig. 5. The algorithm of the tested vehicle control with a possible to apply feedback

Rys. 5. Algorytm sterowania obiektem badań z możliwym do zastosowania sprzężeniem zwrotnym

drive system. The current study does not include feedback associated with the specified driving speed (dashed line in Fig. $3)$. The lack of verification of the vehicle speed and related to it adjustment of the accelerator pedal setting contributed to obtaining significant differences in driving speeds depending directly on the battery charge degree.

The parameters of the system operation were recorded with a frequency of approx. $0.7 \mathrm{~Hz}$. The range of the sampling frequency changes is shown in Fig. 6. The calculated value of the coefficient of variation for frequency $-\mathrm{CoV}(\mathrm{f})$ - after the proportionate enlargement by the value of a random variable of student's t-test distribution (1.860 for $\alpha=0.1 ; \mathrm{k}=8$ ) obtained values less than $0.4 \%$. This value illustrates only variation of this parameter in relation to the arithmetic mean.

The vehicle speeds obtained during the tests depend on, among others, such factors as: the currently set values of the input, the level of battery charge and conditions of the combustion engine start up. The characteristics of the driving speeds values at subsequent measuring points of the tests are shown in Fig. 7.

a)

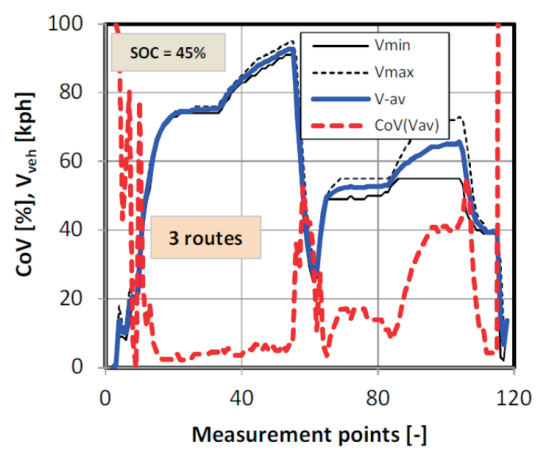

b)

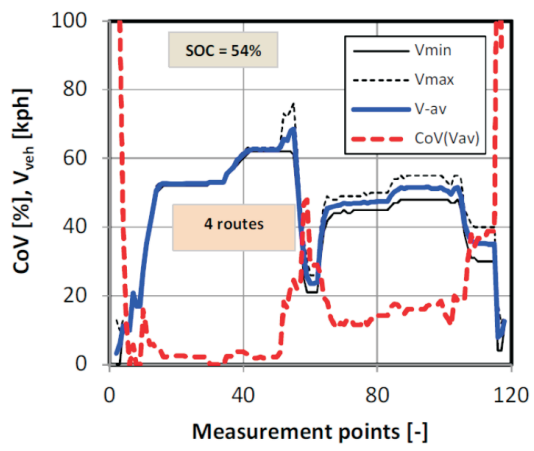

próbkowania przedstawiono na rys. 6. Obliczona wartość współczynnika zmienności $\mathrm{CoV}(\mathrm{f})$, po proporcjonalnym powiększeniu o wartość zmiennej losowej rozkładu t-Studenta (1,860 dla $\alpha=0,1 ; \mathrm{k}=8)$, przyjmowała poziom poniżej $0,4 \%$. Wartość ta obrazuje jedynie zmienność tego parametru względem średniej arytmetycznej.

Uzyskane prędkości pojazdu w czasie badań zależały między innymi od takich czynników, jak: bieżące wartości zadanego wymuszenia, stopień naładowania akumulatora oraz warunki uruchomienia silnika spalinowego. Przebieg wartości prędkości jazdy w kolejnych punktach pomiarowych testów przedstawiono na rys. 7.

Podstawą porównania przebiegów poszczególnych prędkości pojazdu był współczynnik zmienności $\operatorname{CoV}\left(\mathrm{V}_{\mathrm{av}}\right)$ wyznaczony zgodnie z równaniem (3). Analiza porów-

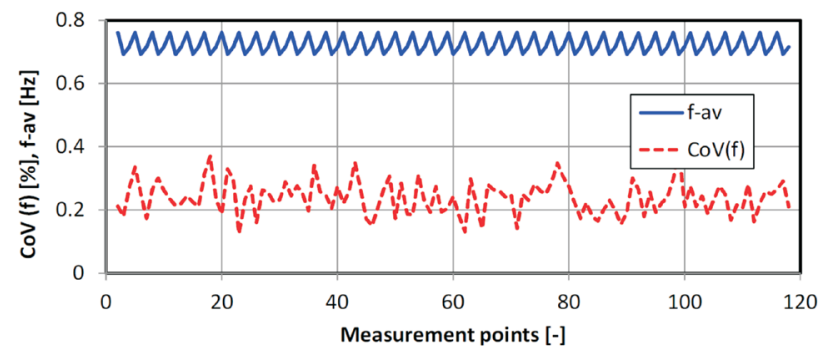

Fig. 6. Analysis of sampling frequency and its distributions Rys. 6. Analiza częstotliwości próbkowania i jej rozrzutów

nawcza wskazuje, że uzyskiwane wartości prędkości jazdy cechują się dużą powtarzalnością w obszarach jazdy ze stałą prędkością $\left(\mathrm{CoV}\left(\mathrm{V}_{\mathrm{av}}\right)<10 \%\right)$. Uruchomienie silnika spalinowego przyczynia się do uzyskiwania większych prędkości jazdy; można to zauważyć, porównując wartości od 15. do 60. punktu pomiarowego testów należących do różnych grup. Współczynnik zmienności uśrednionej prędkości jazdy przyjmował większe wartości $\left(\mathrm{CoV}\left(\mathrm{V}_{\mathrm{av}}\right)>\right.$ $>20 \%$ ) w obszarach zmiany przyspieszenia (dodatniego oraz ujemnego). Powodem tego było przesunięcie w czasie porównywalnych punktów pomiarowych. Największe wartości $\mathrm{CoV}\left(\mathrm{V}_{\mathrm{av}}\right)$ przypadały w obszarach poruszania się pojazdu z najmniejszą prędkością jazdy $\left(\mathrm{V}_{\mathrm{av}}<20 \mathrm{~km} / \mathrm{h}\right)$.

c)

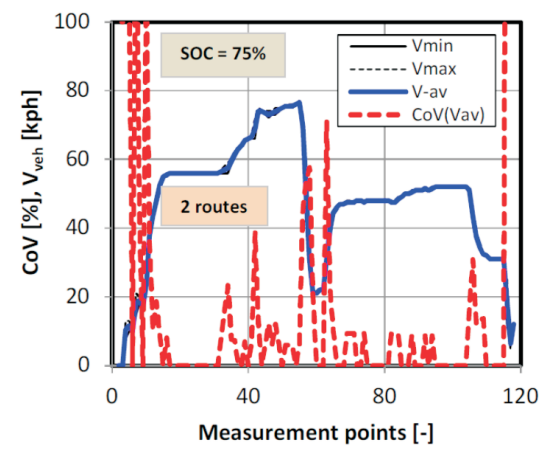

Fig. 7. Conditions of the vehicle driving speed repeatability with hybrid drive system and the variations of distribution values at varying battery charge levels: a) $45 \%$, b), approx. $54 \%$, c) approximately $75 \%$

Rys. 7. Warunki powtarzalności prędkości jazdy pojazdu z układem napędu hybrydowego oraz wartości rozrzutów przy różnym stopniu naładowania akumulatorów: a) $45 \%$, b) około $54 \%$, c) $75 \%$ 
The basis for comparison of the various vehicle speeds was the coefficient of variation for $\mathrm{V}_{\mathrm{av}}$ determined in accordance with the equation (3). A comparative analysis shows that the obtained driving speed values are characterized by high repeatability in the range of constant driving speeds $\left(\mathrm{CoV}\left(\mathrm{V}_{\mathrm{av}}\right)<10 \%\right)$. Start-up of the combustion engine contributes to obtaining higher driving speeds; this can be observed when comparing values from $15^{\text {th }}$ to $60^{\text {th }}$ measuring point in tests for different groups. Coefficient of variation for an averaged driving speed obtained higher values $\left(\mathrm{CoV}\left(\mathrm{V}_{\mathrm{av}}\right)\right.$ $>20 \%$ ) within the range of acceleration changes (both positive and negative). The reason for this was the time offset of comparable points of measurement. The highest values of $\operatorname{CoV}\left(\mathrm{V}_{\mathrm{av}}\right)$ were observed for the vehicles moving with the lowest driving speed $\left(\mathrm{V}_{\mathrm{av}}<20 \mathrm{kph}\right)$.

\section{Repeatability assessment of operating indexes in hybrid propulsion systems}

\subsection{Evaluation of the repeatability in the context of type-approval steady cycle tests}

The conditions of type-approval tests repeatability, presented in Chapter 1, in relation to the vehicles engines tests were used to assess the repeatability of the driving speed in own tests. Using a linear regression equation for average speed $\left(\mathrm{V}_{\mathrm{av}}\right)$ and instantaneous speed $\left(\mathrm{V}_{\mathrm{veh}}\right)$ for each test its form was determined along with the parameters specified in Table 1. The results of these operations are shown in Figure 8.

The analysis of the obtained values of the linear regression coefficients indicates that the coefficient of determination $\mathrm{R}^{2}$ in only one case is less than it is assumed in the guidelines for dynamic tests of the engines (in relation to the engine speed). The value of the coefficient $\mathrm{R}^{2}$ less than 0.97 was obtained during one test run of a vehicle for $\mathrm{SOC}=$ $=54 \%$ (Fig. $8 \mathrm{~b}$ ). The coefficient of linear regression a (slope) also in only one case was outside the range given in Table 1. It is, therefore, possible to use the limits of tolerance established for dynamic tests of combustion engines - in relation to the speed of the vehicle in dynamic tests of hybrid drive systems.

\subsection{Repeatability assessment of operating indexes in tests}

The reasons for operation of a combustion engine in the hybrid drive system may be as follows: temporary needs of

\section{Ocena powtarzalności wskaźników pracy układu napędu hybrydowego}

\subsection{Ocena powtarzalności na tle homologacyjnych testów stacjonarnych}

Przedstawione $\mathrm{w}$ rozdziale 1 warunki powtarzalności testów homologacyjnych w odniesieniu do badań silników pojazdów wykorzystano do oceny powtarzalności prędkości jazdy własnego testu badawczego. Stosując równanie regresji liniowej do prędkości średniej $\left(\mathrm{V}_{\mathrm{av}}\right)$ i prędkości chwilowej $\left(\mathrm{V}_{\text {veh }}\right)$ każdego z testów, wyznaczono jego postać wraz $\mathrm{z}$ wielkościami scharakteryzowanymi w tabeli 1 . Wyniki tych prac przedstawiono na rys. 8 .

Analiza uzyskanych wartości współczynników regresji liniowych wskazuje, że współczynnik determinacji $\mathrm{R}^{2} \mathrm{w}$ jednym tylko przypadku wynosi mniej niż zakładają wytyczne badań silników w testach dynamicznych (w odniesieniu do prędkości obrotowej silnika). Wartość współczynnika $\mathrm{R}^{2}$ poniżej 0,97 uzyskano podczas jednej próby badawczej pojazdu z SOC $=54 \%$ (rys. 8b). Współczynnik regresji liniowej a (nachylenia prostej) również tylko w jednym przypadku jest poza zakresem podanym w tablicy 1. Możliwe jest więc wykorzystanie - ustalonych dla testów dynamicznych silników spalinowych - limitów tolerancji w odniesieniu do prędkości pojazdu w testach dynamicznych układów napędów hybrydowych.

\subsection{Ocena powtarzalności wskaźników pracy w teście badawczym}

Powodem uruchomienia silnika spalinowego w układzie napędu hybrydowego mogą być takie czynniki, jak: bieżące polecenia kierowcy, mały stopień naładowania akumulatora czy duża prędkość jazdy. Prędkości obrotowe silnika spalinowego w kolejnych punktach testu przedstawiono na rys. 9.

Analiza uzyskanego współczynnika zmienności prędkości obrotowej silnika spalinowego $(\mathrm{CoV}(\mathrm{n}))$ wykazała powtarzalność tej prędkości w porównywanych punktach pomiarowych (rys. 9a). Silnik spalinowy przez większość czasu pracy ma prędkość z zakresu 1200-1500 obr/min. Małe wartości współczynnika zmienności $(\mathrm{CoV}(\mathrm{n})<5 \%)$ w tych punktach zależą od niewielkiego odchylenia standardowego prędkości obrotowej w porównaniu do jej średniej arytmetycznej. Silnik spalinowy pracował w zbliżonym zakresie czasowym. Dowodem tego jest zwiększona war- a)

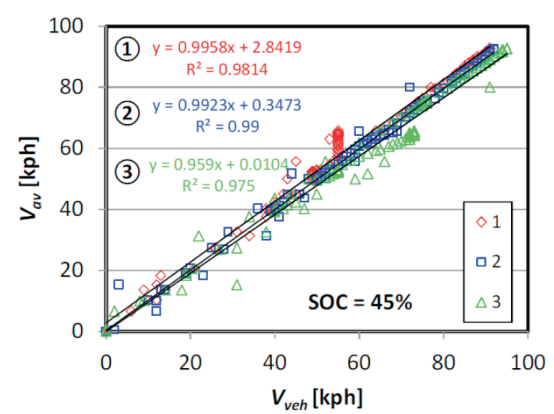

b)

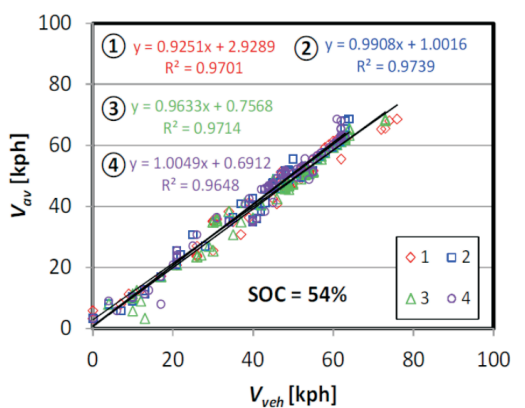

c)

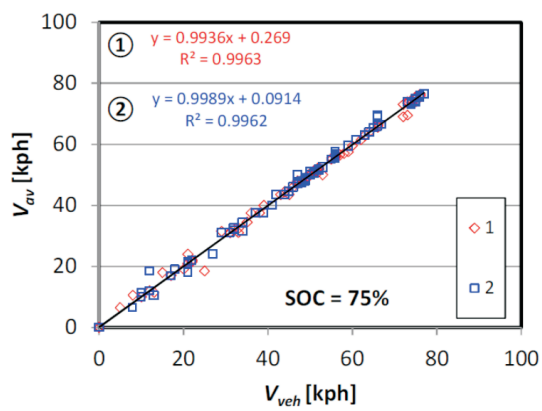

Fig. 8. The analysis of linear regression of average and instantaneous speed value in the tests runs at different initial SOC: a) $45 \%$, b) $54 \%$, c) $75 \%$ Rys. 8. Analiza regresji liniowej wartości prędkości średniej i chwilowej testu badawczego przy zróżnicowanym początkowym SOC: a) 45\%, b) 54\%, c) 75\% 
the driver, the low level of high voltage battery charge or high driving speed. The combustion engine speeds at particular points of the test are presented in Figure 9.

Analysis of the obtained variation coefficient of combustion engine speed $(\mathrm{CoV}(\mathrm{n}))$ indicated repeatability of this parameter in the compared measurement points (Fig. 9a). The combustion engine for most of the operating time has the speed ranging from 1200-1500 rpm. Low values of the coefficient of variation $(\mathrm{CoV}(\mathrm{n})<5 \%)$ in these points depend on relatively small standard deviation of engine speed compared to its arithmetic mean. The combustion engine operated in similar time range. This was proved by the increased value of the coefficient of variation $(\mathrm{CoV}(\mathrm{n})$ $>30 \%$ ) only in individual measuring points. In Figures $9 \mathrm{~b}$ and $9 \mathrm{c}$ significant differences in conditions of the combustion engine start-up are observed, despite similar level of battery charge (SOC approx. 54\%). This may be associated with the fact of obtaining the value of the charge sufficient to operate the so-called charge sustaining mode. This means lack of full charging, and only momentary charge and discharge within a limited range of SOC changes.

Analogous to the assessment of driving speed repeatability in own tests, an assessment of the combustion engine speed repeatability was performed. The results are presented in Fig. 10. The results indicate that the coefficient of determination below $95 \%$ was obtained only during a single test run with the lowest battery charge level (Fig. 10a). In other tests, this value exceeds $97 \%$. The determined value of the tość współczynnika zmienności $(\mathrm{CoV}(\mathrm{n})>30 \%)$ jedynie w pojedynczych punktach pomiarowych. Na rysunku $9 \mathrm{~b}$ i 9c widoczne są duże różnice w warunkach uruchomienia silnika spalinowego, mimo zbliżonego poziomu stopnia naładowania akumulatora (SOC ok. 54\%). Może to wynikać z uzyskania wartości naładowania wystarczającej do działania trybu tzw. podtrzymania ładowania akumulatora. Stan ten oznacza brak pełnego doładowywania, a jedynie jego chwilowe doładowanie i rozładowanie w ograniczonym zakresie zmian SOC.

Podobnie do oceny powtarzalności prędkości jazdy własnego testu badawczego, wykonano ocenę powtarzalności prędkości obrotowej silnika spalinowego. Rezultaty zaprezentowano na rys. 10. Wynika z nich, że współczynnik determinacji poniżej 95\% uzyskano tylko podczas jednego przejazdu z najmniejszym stopniem naładowania akumulatora (rys. 10a). W pozostałych testach wartość ta wynosi powyżej 97\%. Wyznaczona wartość współczynnika regresji liniowej a wskazuje na zwiększone różnice również przy małej wartości naładowania akumulatora. $\mathrm{W}$ tym przypadku wartości podane w tablicy 1 nie są zachowane. Wartości rzeczywiste tego współczynnika wynoszą około 0,83 , przy wymaganej minimalnej wartości 0,95 . Odchylenie to nie jest spowodowane jedynie wyłączaniem silnika spalinowego (wartości w okolicy zera), lecz również jego większymi wartościami, niekoniecznie mającymi związek z rozruchem silnika spalinowego.

W badaniach dokonano także analizy zmian przyspieszenia ruchu pojazdu (dodatniego i ujemnego) wraz z analizą współ-

b)
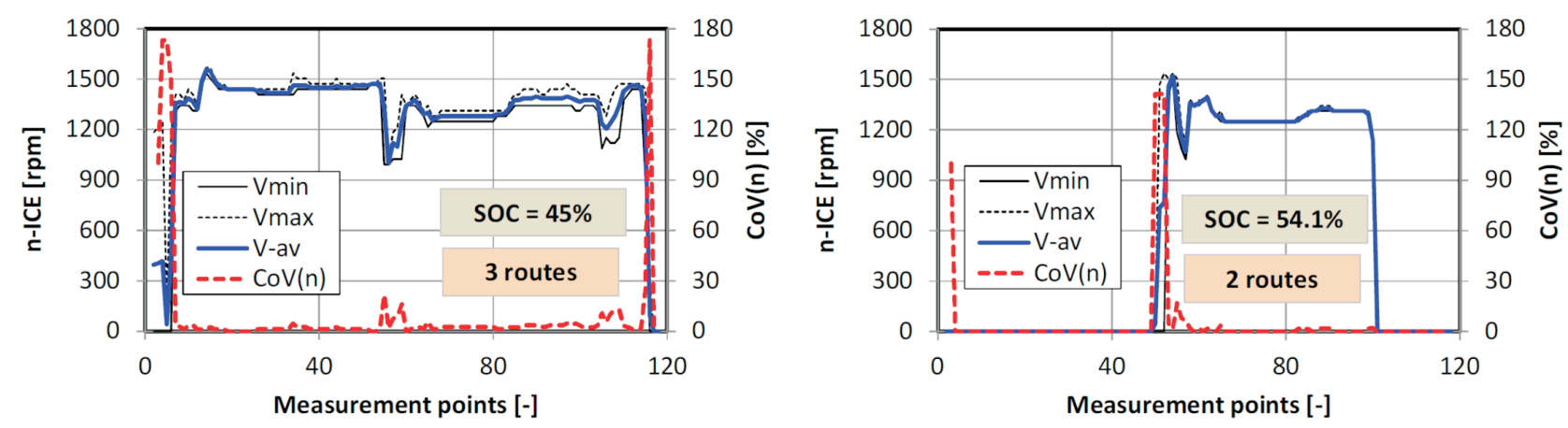

d)

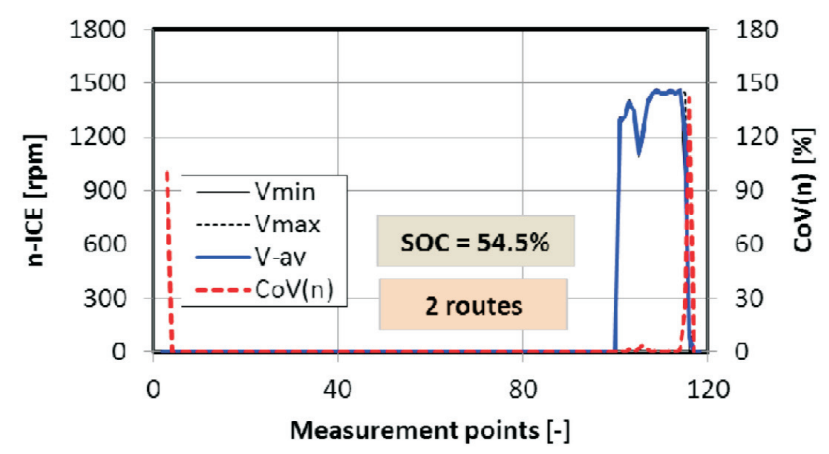

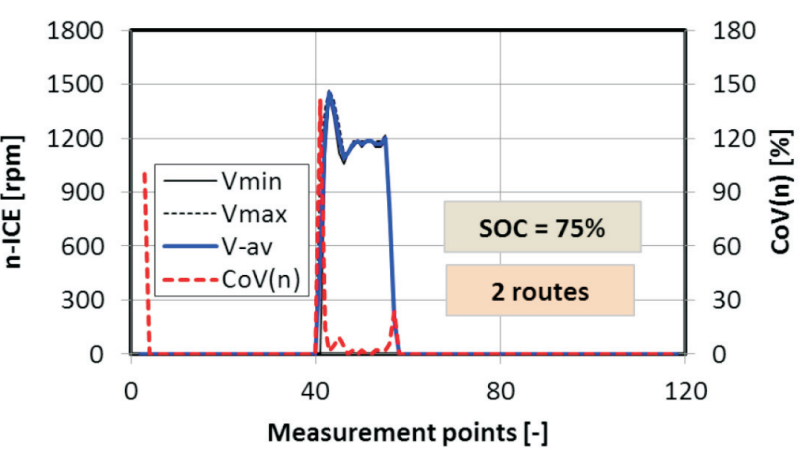

Fig. 9. Conditions of repeatability of the combustion engine speed with hybrid drive system and the variations of distribution values at varying battery charge levels: a) $45 \%$, b) $54.1 \%$, c) $54.5 \%$, d) $75 \%$

Rys. 9. Warunki powtarzalności prędkości obrotowej silnika spalinowego pojazdu z układem napędu hybrydowego oraz wartości rozrzutów przy różnym stopniu naładowania akumulatorów: a) $45 \%$, b) $54,1 \%$, c) $54,5 \%$, d) $75 \%$ 
a)

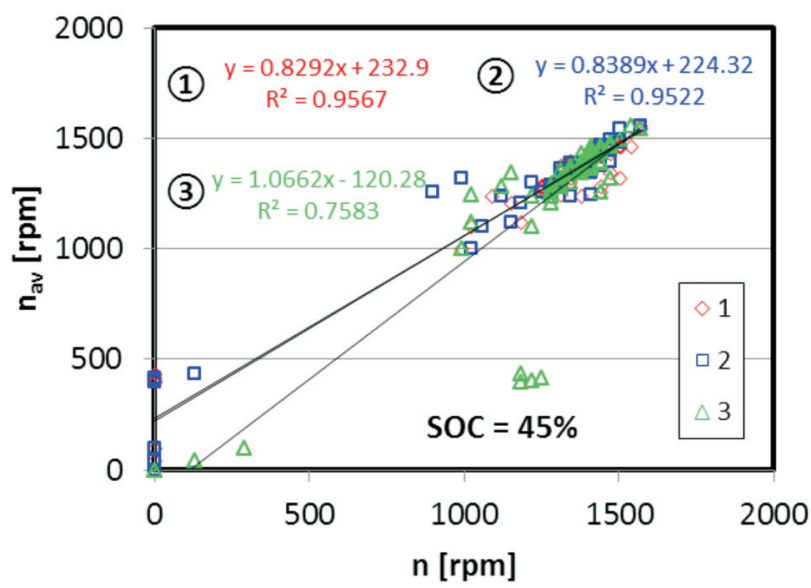

c)

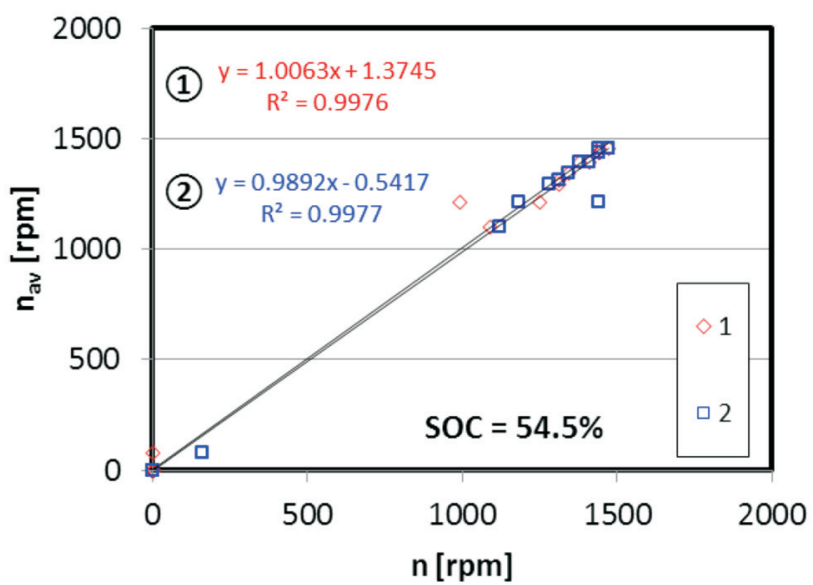

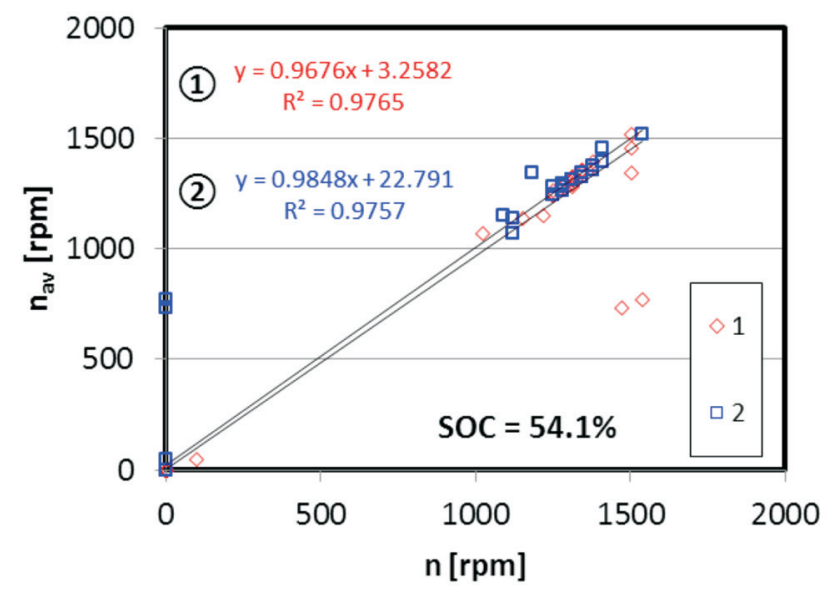

d)

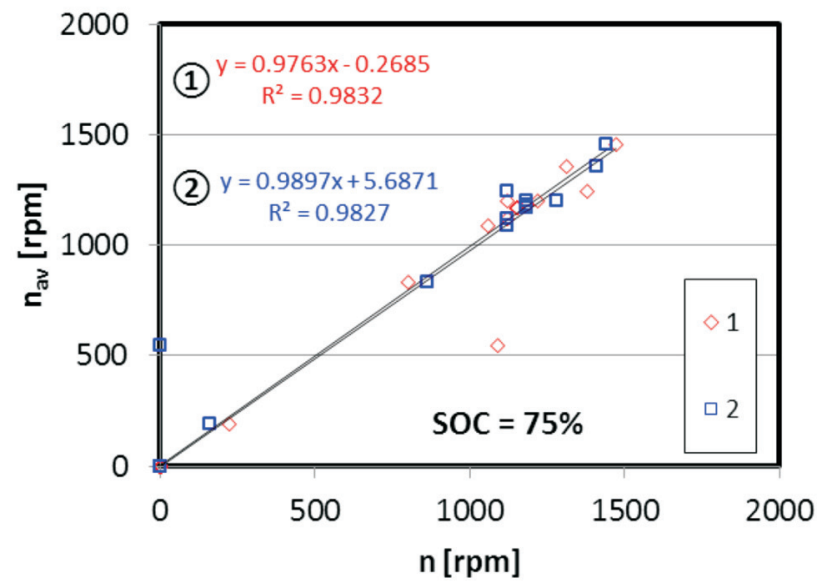

Fig. 10. The analysis of linear regression of average and instantaneous combustion engine speed value in the tests runs at different initial SOC: a) $45 \%$, b) $54.1 \%$, c) $54.5 \%$, d) $75 \%$

Rys. 10. Analiza regresji liniowej średniej i chwilowej wartości prędkości silnika spalinowego w teście badawczym przy zróżnicowanym początkowym SOC: a) $45 \%$, b) $54,1 \%$, c) $54,5 \%$, d) $75 \%$

coefficient of the linear regression a indicates increased differences also at low battery charge level. In this case, the values given in Table 1 are not maintained. The actual values of this coefficient are about 0.83 , at a required minimum value of 0.95 . This deviation is caused not only by turning the combustion engine off (value around zero), but also by its higher values, not necessarily related to the combustion engine start-up.

In the tests also the analysis of the vehicle acceleration changes (positive and negative) was conducted, along with the analysis of the coefficient of variation (Fig. 11). From the analysis of the figures it can be observed, that the acceleration values do not depend on the battery charge level, while the values of the coefficient of variation for the vehicle speed are related to this index. An increase in the battery charge level results in lower values of coefficient of variation for delay variability.

The analysis of the mean values of changes in vehicle speeds in relation to the acceleration phases indicates existence some relation with the battery charge level (Fig. 12). czynnika zmienności (rys. 11). Z analizy rysunków wynika, że wartości przyspieszenia nie zależą od stopnia naładowania akumulatora, jednak wartości współczynnika zmienności prędkości pojazdu są zależne od tego wskaźnika. Zwiększenie stopnia naładowania akumulatora skutkuje mniejszymi wartościami współczynnika zmienności opóźnienia.

Analiza średnich wartości zmian prędkości pojazdu w odniesieniu do faz przyspieszania wskazuje na istnienie ich zależności od stopnia naładowania akumulatorów (rys. 12).

Podczas hamowania (a $<0 \mathrm{~m} / \mathrm{s}$ ) zmiany prędkości są największe i maleją wraz z uzyskiwaniem dodatniego przyspieszenia pojazdu. Dla małych SOC faza braku przyspieszania i przyspieszania dodatniego wskazuje na podobne wartości zmian prędkości jazdy. Zwiększenie stopnia naładowania akumulatora zmniejsza ponownie zmienność prędkości jazdy.

Duży stopień naładowania akumulatorów podczas dodatnich przyspieszeń wskazuje na zwiększenie $\operatorname{CoV}\left(\mathrm{V}_{\mathrm{av}}\right)$, co może wynikać z dostępności większej wartości momentu obrotowego silnika elektrycznego niż silnika spalinowego. 
a)

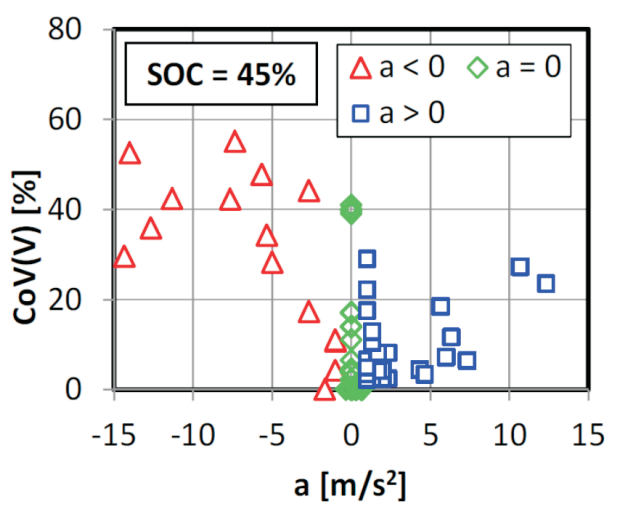

b)

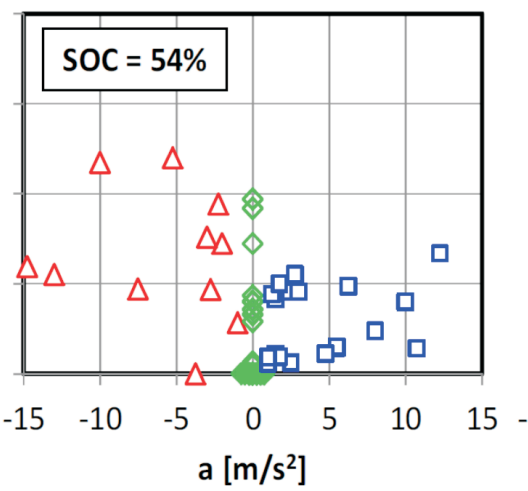

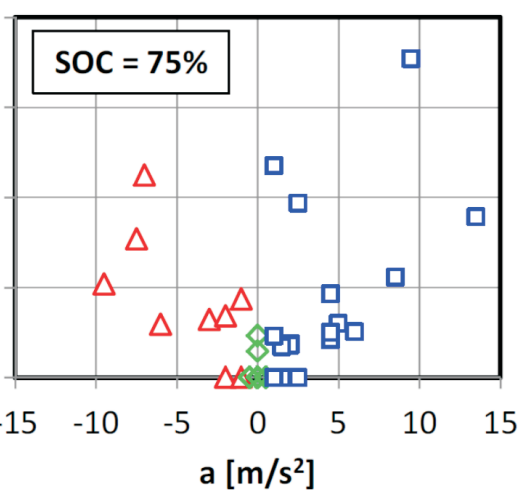

Fig. 11. The instantaneous values of vehicle speeds distribution with division into a braking phase, constant speed phase and acceleration phase in relation to the battery charge level: a) $45 \%$, b) approx. $54 \%$, c) $75 \%$

Rys. 11. Chwilowe wartości rozrzutów prędkości pojazdu z podziałem na fazy opóźnienia, stałej prędkości i przyspieszania w zależności od stopnia naładowania akumulatorów: a) 45\%, b) około $54 \%$, c) $75 \%$

During braking $(\mathrm{a}<0 \mathrm{~m} / \mathrm{s})$ the speed changes are the highest and decrease as the positive acceleration of the vehicle is being achieved. For low values of SOC, the phase with no acceleration and with positive acceleration show similar values of driving speed changes. An increase in the level of battery charge reduces the variation of driving speed again.

A high battery charge level during positive acceleration indicates an increased $\operatorname{CoV}\left(\mathrm{V}_{\mathrm{av}}\right)$, which may result from the availability of higher torque of an electric motor compared to the combustion engine torque. This means the possibility of a rapid increase in the driving force on the vehicle wheels and, at the same time, leads to increased fluctuations in the vehicle speeds. Such conditions of driving system operation also result in lowest changes in the set driving speed of the vehicle. What it means is that the vehicle with hybrid drive system operates in the electric mode.

\section{Summary}

Reproducibility analysis of hybrid drive systems operating conditions indicates:

1. The possibility of precise mapping of the position of accelerator pedal in the hybrid drive system; however, the conditions of such control do not define unequivocally the driving vehicle speed or the operating conditions of particular hybrid drive systems.

2. The input signal of the external load in hybrid drive system causes different operating conditions for combustion engine and hybrid propulsion system; simultaneously the result of such a control is varied operation of the electric motors.

Repeatability analysis of the operating conditions of hybrid drive systems leads to the following conclusions:

1. The level of high-voltage battery charge has a determining influence on the repeatability of system operation indexes; a high battery charge level results in a limited share of the combustion engine operation time during the entire test.

2. A low level of high-voltage battery charge enforces an increased share of combustion engine operation time; that
Oznacza to możliwość gwałtownego zwiększenia siły napędowej na kołach pojazdu i jednocześnie prowadzi do zwiększenia fluktuacji prędkości pojazdu. Taki stan pracy układu napędowego skutkuje również najmniejszymi zmianami ustalonej prędkości jazdy pojazdu. Oznacza to tryb elektryczny jazdy pojazdu z układem napędu hybrydowego.

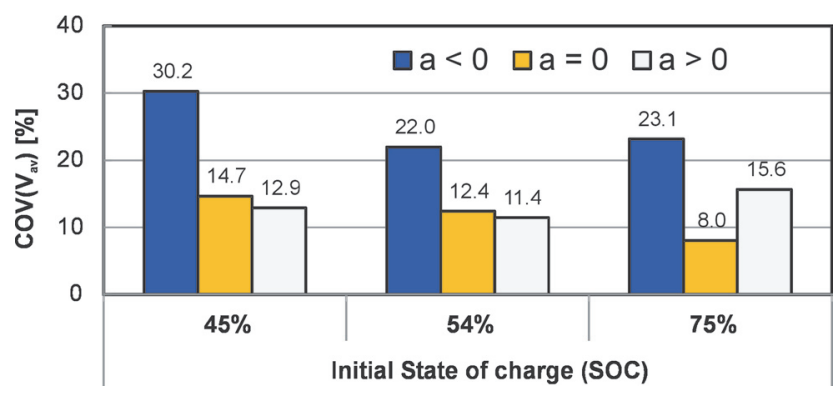

Fig. 12. The mean values of vehicle speeds distribution with division into a braking phase, constant speed phase and acceleration phase

Rys. 12. Średnie wartości rozrzutów prędkości pojazdu z podziałem na fazy opóźnienia, stałej prędkości i przyspieszania

\section{Podsumowanie}

Analiza odtwarzalności warunków pracy układu napędu hybrydowego prowadzi do wniosków:

1. Istnieją możliwości pełnego odwzorowania położenia pedału przyspieszenia w układzie napędu hybrydowego; jednak warunki takiego sterowania jednoznacznie nie definiują prędkości jazdy pojazdu oraz warunków pracy poszczególnych układów napędu hybrydowego.

2. Wymuszenie zewnętrznego obciążenia układu napędu hybrydowego powoduje odmienne warunki pracy silnika spalinowego oraz układu napędu hybrydowego; skutkiem takiego sterowania jest jednocześnie zróżnicowana praca silników elektrycznych układu napędowego;

natomiast analiza powtarzalności warunków pracy układu napędu hybrydowego prowadzi do następujących wniosków:

1. Decydujący wpływ na powtarzalność wskaźników pracy układu ma stopień naładowania akumulatora wysoko- 
share is not proportional to the degree of high-voltage battery discharge (defined by SOC index).

3. A reduced battery charge level, at a defined accelerator pedal position, results in an increased value of combustion engine torque in order to ensure the high-voltage battery charging.

4. Low values of battery charge (SOC) additionally result in higher driving speeds of a vehicle due to higher value of combustion engine speed and torque, necessary to supplement the battery energy. napięciowego; duży stopień jego naładowania skutkuje ograniczonym udziałem czasu pracy silnika spalinowego w czasie trwania calego testu.

2. Mały stopień naładowania akumulatora wysokonapięciowego wymusza zwiększony udział czasu pracy silnika spalinowego; udział ten nie jest proporcjonalny do stopnia rozładowania akumulatorów wysokonapięciowych (określony przez wskaźnik SOC).

3. Ograniczony stopień naładowania akumulatora powoduje, przy ustalonej wartości położenia pedału przyspieszenia, zwiększoną wartość momentu obrotowego silnika spalinowego w celu zapewnienia doładowania akumulatora wysokonapięciowego.

4. Małe wartości SOC akumulatora skutkują dodatkowo większymi prędkościami jazdy pojazdu dzięki większej wartości prędkości i momentu obrotowego silnika spalinowego, koniecznej do uzupełnienia energii akumulatora.

\section{Bibliography/Literatura}

[1] Balicki A., Makać W. Metody wnioskowania statystycznego, Wydawnictwo Uniwersytetu Gdańskiego, Gdańsk 2007.

[2] Cieślik W., Pielecha I., Szałek A. Assessment of parameters of the hybrid drive system in vehicles in urban traffic conditions. Combustion Engines. 2015, 161(2), 14-27.

[3] Cieślik W., Pielecha I., Szałek A. Indexes of performance of combustion engines in hybrid vehicles during the UDC test. Combustion Engines. 2015, 160(1), 11-25. ISSN 23009896.

[4] Directive 1999/96/EC of the European Parliament and of the Council on the approximation of the laws of the Member States relating to measures to be taken against the emission of gaseous and particulate pollutants from compression ignition engines for use in vehicles, and the emission of gaseous pollutants from positive ignition engines fuelled with natural gas or liquefied petroleum gas for use in vehicles and amending Council Directive 88/77/EEC, 13.12.1999, www.eea.europa. eu (accessed 5.02.2016).

[5] Dyrektywa Rady z dnia 20 marca 1970 r. w sprawie zbliżenia ustawodawstw Państw Członkowskich odnoszących się do działań, jakie mają być podjęte w celu ograniczenia zanie-

Ireneusz Pielecha, DSc., DEng. - professor in the Faculty of Machines and Transport at Poznan University of Technology.

Dr hab. inż. Ireneusz Pielecha, prof. PP-profesor na Wydziale Maszyn Roboczych i Transportu Politechniki Poznańskiej.

e-mail: ireneusz.pielecha@put.poznan.pl

Wojciech Cieślik, MEng. - postgraduate in the Faculty of Machines and Transportation at Poznan University of Technology.

Mgr inż. Wojciech Cieślik - doktorant na Wydziale Maszyn Roboczych i Transportu Politechniki Poznańskiej.

e-mail:wojciech.m.cieslik@doctorate.put.poznan.pl czyszczania powietrza przez emisje z pojazdów silnikowych (70/220/EWG) ze zmianami; eur-lex.europa.eu (accessed 3-02-2016).

[6] Global Technical Regulation No. 4. Test procedure for compression-ignition (C.I.) engines and positive ignition (P.I.) engines fuelled with natural gas (NG) or liquefied petroleum gas (LPG) with regard to the emission of pollutants, ECE/ TRANS/180/Add.4, 25.01.2007, www.unece.org (accessed 5.02.2016).

[7] Global Technical Regulation No. 11. Engine emissions from agricultural and forestry tractors and from non-road mobile machinery, ECE/TRANS/180/Add.11, 9.03.2010, www.unece. org (accessed 5.02.2016).

[8] Merkisz J., Pielecha J., Radzimirski S. Emisja zanieczyszczeń motoryzacyjnych w świetle nowych przepisów Unii Europejskiej.WKŁ, Warszawa 2012.

[9] Merkisz J., Pielecha J., Radzimirski S. Pragmatyczne podstawy ochrony powietrza atmosferycznego w transporcie drogowym. Wydawnictwo Politechniki Poznańskiej, Poznań 2009.

[10] Part 86-Control of emissions from new and in-use highway vehicles and engines. Subpart B-Emission Regulations for 1977 and Later Model Year New Light-Duty Vehicles and New Light-Duty Trucks and New Otto-Cycle Complete HeavyDuty Vehicles; Test Procedures. $\$ 86.115-78$ EPA dynamometer driving schedules, www.ecfr.gov (accessed 3.02.2016).

[11] Serdecki W. Badania silników spalinowych. Wydawnictwo Politechniki Poznańskiej, Poznań 2012.

[12] Worldwide Harmonized Light Vehicles Test Procedure. Global Technical Regulation on Worldwide Harmonized Light Vehicles Test Procedure. ECE/TRANS/180/Add.15, 12.05.2014, www.unece.org (accessed 2.02.2016).

Michał Siwoń, Eng. - student in the Faculty of Machines and Transportation at Poznan University of Technology.

Inż. Michat Siwoń-student na Wydziale Maszyn Roboczych i Transportu Politechniki Poznańskiej. e-mail:michal.siwon@student.put.poznan.pl

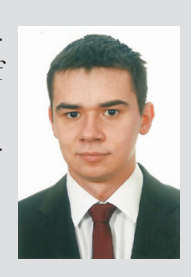

